\title{
Using the Cognitive Research Trust Scale to Assess the Implementation of the Elements of Higher-Order Thinking Skills in Malay Language Teaching and Learning
}

\author{
Anida Sarudin, Husna Faredza Mohamed Redzwan, Intan Safinas Mohd Ariff Al-Bakri, \\ Zulkifli Osman
}

\begin{abstract}
The aim of this study is to assess the teaching practices of Malay Language teachers in implementing the elements of higher-order thinking skills in the teaching and learning of Malay Language using the Cognitive Research Trust (CoRT) Scale. Essentially, the scales comprises six devices, namely CoRT 1 (Breadth), CoRT 2 (Organization), CoRT 3 (Interaction), CoRT 4 (Critical Thinking), CoRT 5 (Information and Feeling), and CoRT 6 (Action) that are related to CoRT tests, namely PMI (Plus, Minus, Interesting), CAF (Consider All Factors), C\&S (Consequence \& Sequel), AGO (Aims, Goal, Objectives), FIP (First, Important, Priorities), APC (Alternatives, Possibilities, Choice), and OPV (Other People's Views). This study used a qualitative approach using the observation method to elicit data from a study sample consisting of six Malay Language teachers from several schools with as sizeable indigenous or Orang Asli student population in the district of Batang Padang. A descriptive qualitative analysis was conducted to draw pertinent findings of the teachers' understanding and practices of HOTS. The analysis of the data revealed that the teaching and learning of the subject matter were infused with the elements of HOTS, with the teachers employing a combination of the CoRT devices and thinking techniques. Such an infusion of skills was made evidently clear by students' answers that demonstrated high critical thinking skills. These findings underscore the importance of using the Cognitive Research Trust Scale to assess the implementation of HOTS in the teaching and learning practice of the Malay Language. In conclusion, the proper and judicious use of CoRT devices and thinking techniques can help students to develop HOTS, which are extremely important to enable them to think and solve problems critically and creatively.
\end{abstract}

Keywords: High Order Thinking Skills (HOTS), Cognitive Research Trust Scale, Malay pedagogy, Malay teachers, Indigenous schools.

\section{Revised Manuscript Received on June 22, 2019.}

Anida Sarudin, Department of Malay Language and Literature, Faculty of Languages and Communication, Sultan Idris Education University

Husna Faredza Mohamed Redzwan, Department of Malay Language and Literature, Faculty of Languages and Communication, Sultan Idris Education University

Intan Safinas Mohd Ariff Al-Bakri, Department of English Language and Literature, Faculty of Languages and Communication, Sultan Idris Education University

Zulkifli Osman, Department of Malay Language and Literature, Faculty of Languages and Communication, Sultan Idris Education University

\section{INTRODUCTION}

This study was carried out with the main aim of examining the practices of Malay Language teachers in implementing higher-order thinking skills (HOTS) in the teaching and learning of the Malay Language. Specifically, the analysis of such practices would highlight the planning, implementation, and reflection feedback with regard to the practice of HOTS in the classroom, curriculum, and pedagogy to help the researchers to measure such a practice based on a standard scale. To gain a holistic, overall picture of such an implementation, this study was designed to examine the extent to which such a practice has been implemented by Malay Language teachers in the teaching and learning process of the Malay Language in several schools with substantial numbers of indigenous or Orang Asli students. Data collected were analyzed with Cognitive Research Trust (CoRT) scale, developed by Edward De Bono (1973), to identify the elements of HOTS that had been infused by the Malay Language teachers in the teaching and learning process in the schools.

\section{LITERATURE REVIEW}

To identify the research gap, the researchers reviewed a number of studies that have been carried out that focused on the application and implementation of HOTS in several areas of disciplines. Such a review revealed that most of the studies carried out cover a range of disciplines and perspectives with respect to the implementation of HOTS in learning, such as the determination of items based on taxonomic level, the models of contents, teaching strategies, and the validation of assessment items, among others Clearly, the process of implementing HOTS in schools has to be carefully scrutinized from various standpoints

For example, a study by Arsaythamby Veloo (2018), which focused on the assessment of testing items, attempted to examine the objective and subjective test items that could be used to determine whether the elements of HOTS have been implemented or otherwise. The objective test that used items with empty space is appropriate for testing memory, facts, names, places, or events.

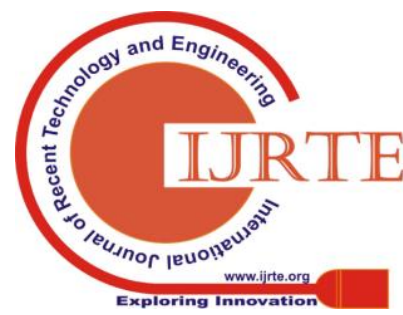


By contrast, such test is not suitable for testing students' behaviors, which are highly unpredictable, such as their creative and critical thinking. In addition, matching items are more relevant to eliciting information that involves numerous matches. On the other hand, for the subjective test, essay items are deemed more appropriate to be used to test higher taxonomic levels, notably at the levels of synthesis and assessment. Clearly, the choice of questionnaire items has to conform to a certain benchmark.

Likewise, a study focusing on the development of HOTS assessment items for Year One Mathematics for the topic of Fraction was carried out by Mazlini Adnan, Najah Mohd Nawi, Mohd Faizal Nizam Lee Abdullah, Che Nidzam Che Ahmad, and Nurul Syakirah Arifin (2018). In their study, they developed 20 such items that were validated by a panel of five experts, the validation of which focused on the suitability of the items with appropriate cognitive levels. Through this validation, all the items were found to be valid in meeting the intended levels of HOTS.

In addition, the implementation aspect of HOTS based on relevant models and theories have also been addressed by several previous studies. For example, a study by Mohd Syaubari and Ahmad Yunus (2016) focused on the elements of HOTS embedded in the teaching practice of Islamic Education teachers, who used several of Imam Ghazali's highly acclaimed scholarly works, namely Ihya Ulumudin, Ayuha Walad, and Minhaj Abidin. Through this study, the researchers proposed and developed three teaching frameworks that can be used to guide the implementation of HOTS in the teaching practice. Such frameworks, however, have been critically criticized for its methodological development that solely relied on the works of one single scholar in one particular discipline.

As highlighted in the literature, several researchers have attempted to examine the impact of the use of specific teaching methods or strategies on the development of students' HOTS. For example, in a study by Chew Fong Peng and Zul Hazmi Hamad (2018), they investigated the use of HOTS in the learning of the Malay Language through the use of a questioning technique. Their investigation revealed that the students would frequently use HOTS in their learning when their teachers used the teaching strategies described as follows: (a) By encouraging students to ask many questions, (b) By examining students' understanding prior to sharing his or her understanding, (c) By encouraging students to express their ideas and opinions, (d) By asking students to state or express their understanding, and (e) By allowing students to respond appropriately, thus enabling the teacher to adopt a certain teaching and learning technique deemed appropriate. Evidently, such studies indicate that the questioning technique with validated question items has been widely used as a benchmark for the implementation of the elements of HOTS in learning.

\section{METHODOLOGY}

As acknowledged, qualitative studies can help researchers gain a holistic, detailed understanding of a certain phenomenon. As such, the researchers used a qualitative approach based on the interview method in carrying out this study in three selected secondary schools in the district of Batang Padang, which has a sizeable population of indigenous students from the Senoi ethnic group, namely the Semai people. Specifically, this study focused on identifying the understanding and practices of HOTS of six Malay Language teachers in teaching such students the subject matter at Form 1 and Form 2 levels.

\section{Research Instrument}

In this study, the researchers examined six thinking devices of the Cognitive Research Trust (CoRT) technique, namely from CoRT 1 to CoRT 6 (refer to Table 1), and elaborated the techniques applied in such thinking devices, namely PMI (Plus, Minus, Interesting),CAF (Consider All Factors), C\&S (Consequence \& Sequel), AGO (Aims, Goal, Objectives), FIP (First, Important, Priorities), APC (Alternatives, Possibilities, Choice), and OPV (Other People's Views. The CoRT technique was introduced by Edward de Bono in 1973. Therefore, the research instrument used in this study was based on an observation checklist, which was used to identify and check the levels of HOTS elements embedded in the teaching and learning process.

The Elements of HOTS based on the Cognitive Research Trust (CoRT) Scale

To stimulate higher-order thinking skills of students, the researchers used the Cognitive Research Trust (CoRT) devices. The application of the CoRT devices, namely CoRT 1, CoRT 2, CoRT 3, CoRT 4, CoRT 5, and CoRT 6, helped establish relationships that were relevant to the thinking techniques. Table 1 summarizes the relationships between such devices and techniques. 
Table.1 Relationships between the CoRT devices (from CoRT 1 to CoRT 6) and Thinking Techniques

\begin{tabular}{|c|c|c|}
\hline CORT 1-6 & \multirow[t]{3}{*}{ ACTION } & Thinking Techniques \\
\hline $\begin{array}{l}\text { CORT 1: } \\
\text { Breadth (Area of perception) }\end{array}$ & & $\begin{array}{l}\text { PMI: } \\
\text { Plus, Minus, and Interesting }\end{array}$ \\
\hline $\begin{array}{l}\text { CORT 2: } \\
\text { Organization (Thinking organization) }\end{array}$ & & $\begin{array}{l}\text { CAF: } \\
\text { Consider All Factors }\end{array}$ \\
\hline $\begin{array}{l}\text { CORT 3: } \\
\text { Interaction }\end{array}$ & & $\begin{array}{l}\text { C\&S: } \\
\text { Consequence \& Sequel }\end{array}$ \\
\hline $\begin{array}{l}\text { CORT 4: } \\
\text { Critical Thinking and Argument }\end{array}$ & & $\begin{array}{l}\text { AGO: } \\
\text { Aims, Goal, and Objectives }\end{array}$ \\
\hline $\begin{array}{l}\text { CORT 5: } \\
\text { Information and Feeling }\end{array}$ & & $\begin{array}{l}\text { FIP: } \\
\text { First Important Priorities }\end{array}$ \\
\hline $\begin{array}{l}\text { CORT 6: } \\
\text { Action }\end{array}$ & & $\begin{array}{l}\text { APC: } \\
\text { Alternatives, Possibilities, and } \\
\text { Choices }\end{array}$ \\
\hline & & $\begin{array}{l}\text { OPV: } \\
\text { Other People's Views }\end{array}$ \\
\hline
\end{tabular}

As highlighted in the above table, teachers can choose and apply a suitable technique to help students invoke the type of thinking based on a specific CoRT device, ranging from CoRT 1 to CoRT 6. Surely, the use of CoRT devices and diverse thinking techniques reflects the depth of thinking of both the teacher and students alike. In particular, the choice of a specific device of CoRT and a thinking technique helps the teacher to be more prepared in using interactive teaching aids in multi-contextual learning to elicit creative, relevant ideas, answers or decisions from students. In this study, the researchers proposed an interpretation score of the strategy of CoRT device and thinking technique as summarized in Table 2.

Table. 2 Interpretation Score

\begin{tabular}{|c|c|}
\hline $\begin{array}{c}\text { Application Strategy of CoRT devices and } \\
\text { Thinking Techniques }\end{array}$ & Level \\
\hline $1-2$ & Low \\
\hline $3-5$ & Moderate \\
\hline$>6$ & Excellent \\
\hline
\end{tabular}

Essentially, the application strategy of CoRT devices and thinking techniques can be viewed as a combination of concepts to help examine the elements of HOTS in the teaching and learning process. As highlighted, the elements of HOTS are considered to be at a low level if the CoRT devices and thinking techniques used mainly involve CoRT 1 and CoRT 2 and PMI and CAF, respectively. Next, for elements of HOTS considered moderate, the CoRT devices and thinking techniques used will be CoRT 3, CoRT 4, and CoRT 5 and C\&S, AGO, and FIP, respectively. Finally, for elements of HOTS considered excellent, the CoRT devices and thinking techniques involved will be CoRT 6 and APC and OPV, respectively.
Using such a score, the researchers were able to identify the level of HOTS practiced by the Malay Language teachers by analyzing their teaching materials, contents, and the interview transcription, revealing that a majority of the elements of HOTS used and practiced were at the low and moderate levels, with only a few elements being at the excellent level. Moreover, the researchers analyzed the same transcription to determine the extent to which HOTS were being practiced in the teaching and learning process by focusing on the relationships between CoRT devices and thinking techniques used. 
Using the Cognitive Research Trust Scale to Assess The Implementation of The Elements of Higher-Order Thinking Skills in Malay Language Teaching and Learning

The analysis revealed that the teachers used 10 combinations of CoRT devices and thinking techniques.

Analysis 1: The application of CoRT 1, CoRT 5, and CoRT 6 and the technique of CAF, FIP, AGO, and APC

Based on the extract of GASMKST as shown in Figure 1, the questions used by the teachers were based on three CoRT devices, namely CoRT 1, CoRT 5, and CoRT 6, placing the students in a learning situation in which they could expand their perception of a given topic. In particular, the discussion initiated and moderated by the teachers used CoRT 5 that involved some elements of emotions and feelings, such as fear and sadness. Later, the teachers applied CoRT by asking their students to think of the action needed when they were in such a situation.

\section{Guru A : Kedua-dua binatang ini, binatang tersayang yang paling disayangi, Buyong la ye?. Baik, permulaan ceritanya macam mana ceritanya? Dan pada awal tahu tak? Bentong berasa? sangat risau, kenapa risau? Macam kamu lah, hujan lebat dan adik kamu tak balik, risau ke tak risau?.}

Pelajar : Risau..

Guru A : Thinisha, adik kamu tak balik waktu hujan lebat. Kenapa kamu risau akan adik kamu yang tak balik-balik?

Pelajar : Saya akan keluar untuk cari dia cikgu.

Guru A : Cari? Tapi, kalau sia-sia je? ok kita balik pada cerita tadi. Bawod. Dia cari tak? baca tak kamu ni cerita tu?

Pelajar : Tak cari, mak dia tak bagi.

Guru A : Kenapa mak dia tak bagi?

Pelajar : Dah malam.

\section{Fig. 1 An Excerpt of Gasmkst}

Embedding the elements of HOTS of the excellent level in teaching was carried out by applying the techniques of Consider All Factors (CAF), OPV (Other People's Views), AGO (Aims, Goals, and Objectives), and APC (Alternatives, Possibilities, Choices). Using the CAF technique, the teachers could receive a number of possible answers from certain students. By contrast, the use of the OPV technique helped the teachers to obtain answers from other students. Meanwhile, the application of the AGO technique guided the teachers to relate a particular situation to the topic of learning; whereas, with the use of the APC technique, the teachers helped students to seek some solution alternatives to a given question. As highlighted in the extract of GASMKST, clearly, the elements of HOTS used in the two-way communication were those of the excellent level.

Analysis 2: The application of CoRT 1, CoRT 2, and CoRT 6 and the technique of CAF Based on the excerpt of
GCSMKT shown in Figure 2, the use of CoRT 1 and CoRT 2 exhibited the skills of the teachers in posing probing questions to students and in expanding the scope of such questions, enabling the students to gain a better insight such that they could provide precise answers. Effectively, in such a teaching and learning process, the students were able to answer articulately. Such articulation in answering the questions by the students was not surprising given that the strategy of using CoRT 1 and CoRT 6 might have helped them to think and formulate a diverse range of answers and to make them become highly active during the questioning session (the expansion of the perception regarding the affection between a man and a woman indicated that the teacher had in fact used CoRT 1 by instructing a male representative and a female representative to prove the application of CoRT 6). 
Pelajar : Kasih sayang.

Cikgu C : Ha, kasih sayang. Apa yang kita boleh kaitkan?

Pelajar : Kasih sayang antara lelaki dan perempuan.

Cikgu C: Mutchandini, Mutchandini nak jawab, apa dia? Silakan Mutchandini.

Pelajar : Perasaan kasih sayang antara lelaki dan perempuan.

Cikgu C : Ya, perasaan kasih sayang antara lelaki dan perempuan. Shakirah, bangun!. Nilai yang dinyatakan pada awal pantun ini, nilai kasih sayang antara lelaki dan perempuan. Sekarang, cikgu nak tanya awak, nilai ini lelaki dan ini perempuan. Sekarang ini, perasaan kasih sayang. Umur macam ni, kasih sayang ni, kasih sayang macam mana yang boleh dibenarkan?

Pelajar : Persahabatan.

Cikgu C : Persahabatan. Very good. Lagi? Ha.

Pelajar : Persaudaraan.

Cikgu C : Persaudaraan. Ok, Firdaus, kasih sayang macam mana pada umur 14 tahun ini?. Fikirkan, kasih sayang macam mana yang dibolehkan?

Pelajar : Kasih sayang antara rakan-rakan.

\section{Fig. 2. An Excerpt of Gasmkst}

Evidently, such a teaching and learning helped established the process of Consider All Factors (CAF), which is a process that takes into account all factors relating to relevant aspects prior to making a decision, action, planning or assessment and that helps students to understand a given problem more comprehensively. In this study, such a process was manifested when the teacher was willing to accept or accommodate students' points of view with regard to affective values, as mentioned in the rhyme which the students stated was about friendship. Clearly, the elements involved in such learning were those of HOTS of the moderate level. Analysis 3: The application of CoRT 2 and the technique of AGO Affirmation is an action that is being carried out to encourage a particular behavior to be repeated. According to Rachlin (1991), the aims of affirmation are to satisfy the needs of an individual and to minimize pressure and stimulate thinking. Referring to the excerpt of GDSMKSAG shown in Figure 3, it was evident that the teachers performed affirmation by referring to previous learning, which helped stimulate students' memory to make them ready for learning and enable them to provide feedback regarding the topic that they had learned previously. In this regard, the use of CoRT 2 by the teacher might have helped him to organize the thinking process of the students to provide feedback. In this study, such mental organization was realized when the teacher reflected on the previous learning of the topic of direct speech and indirect (reported) speech and made a connection of such concepts with the current learning.

$$
\begin{aligned}
& \text { Cikgu D: Shat semua? } \\
& \text { Pelajar : Shat } \\
& \text { Cikgu D: Ok, semalam, ingaat lagi tak, apa yang kita belajar? } \\
& \text { Pelajar : Ingat cakap ajuk dan cakap pindah? } \\
& \text { Cikgu D: Ok, kalau sava tulis di depan, boleh javab lagi tak? } \\
& \text { Pelajar : Boleh. }
\end{aligned}
$$

Fig. 3 An Excerpt of Gdsmksag 
Furthermore, to help identify the aims, goals, and objectives of the learning topic, the teacher used the technique of Aims, Goal, and Objectives (AGO) to carefully weighed in and moderate students' ideas, effectively assisting the teacher to guide the students to relate their ideas with such a topic through relevant examples of direct and indirect speech. Given that the practiced CoRT device and thinking technique were of moderate level, correspondingly the elements of HOTS were of the same level as shown in the excerpt.

Collectively, the findings of the observations suggest that the Malay Language teachers in such a school with a substantial population of Orang Asli students have been practicing HOTS in their teaching quite well. Such a practice is highly commendable as every teacher needs to possess a high-level thinking skill such that he or she can teach his or her studies with a degree of professionalism (Anida Sarudin, 2016, 2017a, 2017b). In this respect, such a teacher plays a significant role in helping his or her students, especially Orang Asli students who are, in general, economically disadvantaged, to develop the essential HOTS. Admittedly, virtually all teachers do know and are aware of the importance of such skills in learning as they have been exposed to such concepts in their teaching training in colleges or universities. As such, teachers not only have to improve their HOTS but also have to apply proper teaching strategies and pedagogies to enable them to help students, notably Orang Asli students, gain such skills.

\section{CONCLUSION}

As demonstrated in this study, clearly the Cognitive Research Trust Scale can serve as an effective assessment tool in determining the effectiveness of the implementation of the elements of HOTS in the teaching and learning process. To help realize such an implementation, a number of thinking techniques and the six CoRT devices can be synergetically combined and applied to infuse such skills in the teaching and learning process. As revealed, it was evidently clear that the teachers of the selected school used a questioning technique based on several CoRT devices and highly stimulating materials to guide their students in generating creative, relevant ideas. Previously, many teachers had some difficulty in knowing whether they had applied the elements of HOTS or not. Such a predicament is now a distant past as the Cognitive Research Trust Scale can be used to effectively gauge the levels of HOTS elements embedded in the learning activities. Interestingly, the findings of this study indicated that the Orang Asli students were not totally left behind compared to those mainstream students and, in fact, some of the students exhibited welldeveloped critical thinking skills, which might be mainly attributed the teaching strategy used by their teachers that helped the former to develop such skills by engaging in learning activities infused with the appropriate elements of HOTS. In conclusion, the proper and judicious use of CoRT devices and thinking techniques can help students to develop HOTS, which are extremely important to enable them to think and solve problems critically and creatively.

\section{ACKNOWLEDGMENT}

The authors wish to express their profound gratitude to the Research Management and Innovation Center, Sultan Idris Education University, for the research grant (Code: GPU 2016-0194- 106-01) that helped fund this research.

\section{REFERENCES}

1. Anida Sarudin, Dahlia Janan, Zulkifli Osman \& Ahmad Khair. (2017a). Linguistics Approach as Teacher Pedagogy in Inculcating Cognitive Aspects of Preschool Children Journal of Applied Environmental and Biological Sciences, 7(1S), 1-11.

2. Anida Sarudin, Husna Faredza, Adenan Ayob dan Zuraini Ramli (2017b). Strategi Efektif Peranti Berfikir Cort (Cognitive Research Trust) Dalam Pendidikan Bahasa Melayu. Prosiding Seminar The 3rd Asia Pasific Conference on Educational Management and Leadership (APCEMAL 2017), 464-479.

3. Anida Sarudin, Dahlia Janan, Zulkifli Osman dan Ahmad Khair. (2016). Penguasaan Bahasa Melayu Kanak-kanak Prasekolah Berdasarkan Inventori Penilaian Kemahiran Terancang. International Journal of Language Education and Applied Linguistics (IJLEAL), 04, 93-106.

4. Anis Shaari \& Aswati Hamzah. (2018) A Comparative Review Of Caring Thinking and Its Implications on Teaching and Learning. Malaysian Journal of Learning and Instruction. Vol. 15 (No. 1), 83-104.

5. Arsaythamby Veloo. (2018). Keupayaan Teori dan Pelaksanaan Pentaksiran dalam Pembelajaran JGD Journal of Governance and Development, 12 Vol.7, 2011 (8 - 15).

6. De Bono, E. (1973). De Bono CoRT thinking teachers notes book 1: Breath MICA Management Resources.

7. Chew Fong Peng \& Zul Hazmi Hamad (2018) Kemahiran Berfikir Aras Tinggi dalam pembelajaran dan pemudahcaraan Bahasa Melayu melalui teknik penyoalan. Jurnal Pendidikan Bahasa Melayu - JPBM (Malay Language Education Journal - MyLEJ). Vol. 8, Bil. 1 (Mei 2018), 1-12.

8. Laura A.W. (2011). The effect of thinking mapson students' higher order thinking skills. US: California State University \& Northridge University.

9. Mazlini Adnan, Najah Mohd Nawi, Mohd Faizal Nizam Lee Abdullah, Che Nidzam Che Ahmad, dan Nurul Syakirah Arifin. (2018). Pembinaan Item Kemahiran Berfikir Aras Tinggi Matematik Tingkatan Satu untuk Topik Pecahan. Jurnal Pendidikan Sains \& Matematik Malaysia. Vol 8, No. 1, 46-54.

10. Mazdi Marzuki, Jabil Mapjabil, Rosmiza Mohd Zainol (2014). Mengupas keciciran pelajar orang asli Malaysia: Suatu tinjauan ke dalam isu aksesibiliti sekolah. Malaysian Journal of Society and Space, Issue 2, 189 198. 
11. Mohd Syaubari \& Ahmad Yunus (2016). Elemen Kemahiran Berfikir Aras Tinggi (KBAT) Di Dalam Amalan Pelajaran Guru Pendidikan Islam Menurut Imam Ghazali. Jurnal Sultan Alauddin Sulaiman Shah, Vol 3, Bil 2, 80-91.

12. Rajendran, N. S. (2010). Teaching thinking skills at institutions of higher learning: Lesson learned. Pertanika Journal of Social Science and Humanities, 18, 1- 14.

13. Surif, J., Ibrahim, N.H., Abdullah, A.H., \& Boon, Y. (2016). Kemahiran Berfikir Aras Tinggi dalam pengajaran dan embelajaran. Johor Bahru: Penerbit Fakulti Pendidikan Universiti Teknologi Malaysia. 